\title{
Fostering Student Authorship
}

Amy R. Mashburn

Sharon E. Rush

Follow this and additional works at: https://digitalcommons.tourolaw.edu/lawreview

Part of the Legal Writing and Research Commons

\section{Recommended Citation}

Mashburn, Amy R. and Rush, Sharon E. (2017) "Fostering Student Authorship," Touro Law Review. Vol. 33: No. 2, Article 5.

Available at: https://digitalcommons.tourolaw.edu/lawreview/vol33/iss2/5

This Perspectives from an Associate Dean: Past, Present, and Future Roles of Law Reviews is brought to you for free and open access by Digital Commons @ Touro Law Center. It has been accepted for inclusion in Touro Law Review by an authorized editor of Digital Commons @ Touro Law Center. For more information, please contact Iross@tourolaw.edu. 


\title{
Fostering STUdent AUTHORShIP
}

\author{
Amy R. Mashburn* and Sharon E. Rush**
}

\section{INTRODUCTION}

Providing students with opportunities to participate in student-run journals is a key component of a quality legal education. Although the current law review publication process leaves much room for improvement, we find the "students benefit" justification for at least some aspects of the status quo compelling. " This rationale recognizes that whatever the deficits of the current publication process may be, students who are involved acquire skills necessary to the practice of law and strengthen their leadership abilities. Because we agree with this assessment, we asked: "[W] hy not establish a program that would require every student to publish a paper?" We realize, of course, that not all students will be able to publish in their school's law review or other student-run journals because there simply is not enough space. In this essay, we suggest that law schools may provide every student with the opportunity to become involved in the process of producing a publishable paper by establishing on-line repositories for student publications. In the paragraphs that follow, we describe what such a program, which we call "student authorship," might look like and further explore several primary benefits that such a program would confer upon students.

\section{A STUdent Authorship Program}

The authorship program we suggest builds, for purposes of illustration, on the current advanced writing requirement at our law school, which we believe is similar to those at a number of law

\footnotetext{
*Associate Dean for Academic Affairs, University of Florida Levin College of Law.

**Associate Dean for Faculty Development, University of Florida Levin College of Law.

1 Johanna K.P. Dennis, The Renaissance Road: Redesigning the Legal Writing Instructional Model, 38 S.U. L. REV. 111, 111-14 (2010).
} 
schools. $^{2}$ Briefly, our students are required to complete a substantial writing requirement that is supervised by a faculty member. ${ }^{3}$ Students who publish in the student-run journals can use their published notes or comments to satisfy this requirement. ${ }^{4}$ Typically, their efforts are supervised by a faculty member chosen by the student or by the faculty adviser to the journal. ${ }^{5}$ Other students satisfy this requirement by writing a seminar paper or doing an independent study that includes the writing requirement. ${ }^{6}$ The policy requires that:

All J.D. candidates must produce - under close faculty supervision - a major, written, finished product that shows evidence of original systematic scholarship based on individual research. Typically, students satisfy this requirement in a seminar course. However, the requirement may also be met through the completion of an approved advanced course, an independent research-advanced writing requirement course, an approved master's thesis or doctoral dissertation certified by a College of Law faculty member or through a note accepted for publication in a co-curricular law school journal as certified by the faculty adviser for the journal. If fulfilled in an advanced course, the required writing may take the form of one or a number of finished written products that together demonstrate these qualities. The general standard for fulfillment of the advanced writing requirement is a paper or papers that are cumulatively

2 Id. at 142-44. For purposes of this essay, we focus on "scholarly" papers, but a program also could be designed to include other types of writing, such as briefs, memoranda, and other types of practice-oriented writings. Notably, we are in the process of designing a proposal for such a student authorship program that we would present to our faculty, which would have to be approved by it. We think there is value in a more inclusive approach and we probably will build this into the proposal.

3 Degree and Residency Requirements, UF LAw: LEVIN C. OF L., https://www.law.ufl.edu/areas-of-study/degree-programs/juris-doctor/degree-and-residencyrequirements (last visited Feb. 12, 2017).

4 Id.

5 Id.

${ }^{6}$ Id. 
at least 25 pages of double-spaced, 12-point text or the equivalent. $^{7}$

Notice that our law school's requirement is missing only the "publication" element and that the quality of the expected writing is otherwise consistent with meeting publication standards. To accomplish our suggested "publication" element, however, student papers would have to conform to accepted styles for citation of authorities. Thus, a valuable part of the publication process for students would include learning a citation system. Learning such a citation system requires attention to detail, mastery of an inter-related set of rules, and careful application of those rules through a rigorous decision-making process. Experience with this aspect of the publication process is, we believe, a practice-related and transferable skill.

Student-run journals lack space to publish all the notes and comments written by their own members, let alone non-members. The existence of an on-line repository remedies this problem. The repository, when indexed by author and subject, will make the papers not published by the law reviews or journals easily accessible and available for others to read, including prospective employers, lawyers, judges, members of the press, and others. ${ }^{8}$

\section{BENEFITS "AUTHORSHIP" CONFERS}

Law schools requiring a publication for graduation would serve multiple purposes, all consistent with the need to improve students' research, writing and other practice-readiness skills. Most would concede that a publication requirement would likely hone students' research, writing and analytical skills. In addition, however, we believe that such a requirement would also confer several less obvious, but related, benefits that lay the foundation for an authorship program.

First, consider that a primary and highly valuable skill we want our students to develop is creative problem-solving. What better way to move toward this goal than to require students to author

\footnotetext{
7 University of Florida Law Student Handbook, UF LAW: LEVIN C. OF L., https://www.law.ufl.edu/life-at-uf-law/office-of-student-affairs/current-students/uf-lawstudent-handbook (last visited Feb. 12, 2017).

8 Richard A. Danner, Issues in the Preservation of Born-Digital Scholarly Communications in Law, 96 LAW LiBR. J. 591, 593-94, 597-98 (2004).
} 
a publication? Scholarship begins, ideally, with a creative idea. Students on law reviews and other student-journals know this all too well. Many of them seek out professors to help them craft their topics. It is not an easy task and often takes hours of research, reflection, and conferring with others before a student settles on a topic. ${ }^{9}$ The importance of authoring an idea cannot be overstated because the process is both analytical and creative. ${ }^{10}$ Additionally, it requires blending established knowledge and sources with new information and insights. ${ }^{11}$ We believe it is a process that all students should expose themselves to because of its unparalleled pedagogical effectiveness.

Secondly, our students will practice law in the era of the "lawyer as problem solver." ${ }^{2}$ The essence of being an outstanding lawyer is the ability to exercise good judgment and form an opinion about how to solve a problem. ${ }^{13}$ When our students begin to practice law, their opinions and evaluations of their clients' cases will matter most, especially to their clients and employers. ${ }^{14}$ Furthermore, students acquiring this skill may be able to distinguish themselves in their externships, internships, and clerkships, thereby helping them find permanent employment. Reaching an opinion, however, requires confidence and building confidence requires guided experience in a low-pressure environment. Our students need opportunities to experiment with analyzing cases while they are in law school to graduate with sufficient confidence to hit the ground running when they begin the practice of law. Participating in an authorship program builds confidence, which we believe will carry over to practice. Students become authors and owners of their own ideas and opinions. They must defend the choices and positions they take in their papers. Moreover, students must take a position that

\footnotetext{
9 Stephanie Martin, How to Pick a Law School Note Topic, Law Sch. Toolbox (Oct. 19, 2012), https://lawschooltoolbox.com/how-to-pick-a-law-school-note-topic/.

10 Neal F. Burstyn, Note, Creative Sparks: Works of Nature, Selection, and the Human Author, 39 COLUM. J.L. \& ARTS 281, 282, 284-85 (2015).

11 Jessica Wherry Clark \& Kristen E. Murray, The Theoretical and Practical Underpinnings of Teaching Scholarly Legal Writing, 1 TEX. A\&M L. REV. 523, 535-36 (2014).

12 Kristina V. Foehrkolb \& Marc A. DeSimone, Jr., Debunking the Myths Surrounding Student Scholarly Writing, 74 MD. L. REv. 169, 174-76 (2014).

13 Id. at 173.

14 Id. at 174; Shawn G. Pearson, Hype or Hypertext? A Plan for the Law Review to Move into the Twenty-First Century, 1997 UTAH L. REV. 765, 795 (1997).
} 
they are confident in to defend. This sense of responsibility and identification with a work product is what we mean by "authorship."

Once a student has identified a topic, further obvious benefits correlated to skills-honing begin to flow. Many of the benefits are rooted in the development of research, writing, analytical and persuasive lawyering skills. ${ }^{15}$ Everyone in law understands the importance of being able to communicate effectively as a lawyer. ${ }^{16}$ Being an author helps students achieve this goal. ${ }^{17}$ As an author, a student has a greater stake, for example, in structuring the argument, guiding the analysis, and making sure the sources he or she relies on actually support the argument. With respect to the research, authors and lawyers must read carefully and evaluate the strengths and weaknesses of different sources and make decisions about which sources are most authoritative and persuasive. Inevitably, simply knowing that the article will be published will motivate the student author to work diligently to strengthen his or her critical thinking skills. ${ }^{18}$

Likewise, a publication requirement will also confer a benefit on law professors and law schools. ${ }^{19}$ Encouraging students and mentoring them while they form opinions as well as assisting them with the process of identifying solutions are part of our responsibilities as educators. Working with students to help them publish a paper is an excellent way for professors to meet their professional responsibilities. This type of guidance is a strength of traditional legal education and one of the best ways, in our opinion, for tenured professors to advance the goal of making students more "practice ready."

15 G.M. Filisko, Law Review: Will It Open Doors For Your Career?, AM. B. Ass'N (Mar. 1, 2014), http://abaforlawstudents.com/2014/03/01/law-review-will-open-doors-career/.

16 Neil J. Dilloff, Effective Communication Tips for Young Lawyers, AM. B. Ass'N Young $\begin{array}{lll}\text { LAW DIVISION 2009), } & \text { (Oct. }\end{array}$ http://www.americanbar.org/content/dam/aba/publishing/young_lawyer/yld_tyl_oct09_com mtips.authcheckdam.pdf.

17 Filisko, supra note 15.

18 Lisa Hackett, Understanding Law Review Success: An Analysis of Factors that Impact Citation Counts (Spring 2013) (unpublished note), http://www.law.msu.edu/king/20122013/Hackett.pdf.

19 Filisko, supra note 15; Menachem Wecker, Law Review Leads to Legal Jobs, Recruiters Say, U.S. News \& World REP. (Jan. 19, 2012, 9:00 AM), http://www.usnews.com/education/best-graduate-schools/top-lawschools/articles/2012/01/19/law-review-leads-to-legal-jobs-recruiters-say. 
Additionally, establishing a student repository would help faculty motivate students to get involved in the intellectual exchange of ideas in a much deeper and more enriching way. ${ }^{20}$ This benefit, although less tangible than the acquisition of skills, is nonetheless very important. A publication requirement would foster strong professional relationships among students and professors. We believe that mentoring and working one-on-one with students is one of the most important roles we can fill as educators. The professional relationships we establish with our students, if fully developed, can last a lifetime. Personally, we owe deep gratitude to several of our professors who continue to play roles in our lives. Similarly, we are in touch with many former students, some of whom were in our first classes decades ago. In fact, as we write this essay, we realize that many of the sustained relationships we have with our law school professors and former students started when we focused on a seminar paper or another writing requirement. We hypothesize that we would strengthen our mentoring relationship with students if they were encouraged and motivated by us, as professors, to publish their work product.

Finally, we recognize that a membership on the law review or another student journal is an honor and students deserve recognition for achieving such an honor. We do not want to detract from their achievements; actually, quite the opposite. Simultaneously, some students who do not make law review or another journal express how marginalized they feel. Some feel they are unlikely to get jobs. Participation in the authorship program will create common ground among students who will all share this similar experience. In fact, the repository could contain student law review members' notes or comments that are not published in the law review. In this way, the repository would not distinguish between law review and non-law review members.

Additionally, the repository would create a bond among all students. A student whose work is published in the repository will feel accomplished for earning such an honor. ${ }^{21}$ Employers and other

20 Brian Farkas, Fixing Law Review Critics, Inside Higher Ed (Nov. 30, 2012), https://www.insidehighered.com/views/2012/11/30/student-run-law-reviews-have-muchcontribute-legal-education-essay\#disqus_thread.

21 Other law schools have established online publication repositories that include student works. Cornell Law School has a Digital Repository which is "a service of Cornell Law Library, [which] provides free permanent online access to published articles, works-inprogress, conference papers, lectures, reports, and workshop presentations produced by 
interested people may even use the articles published in the repository as resources. Likewise, students would have excellent writing samples and faculty would have access to the repository for their own research or for other purposes, such as assisting them in writing letters of recommendation for published students. If we associate our names as faculty with the papers published in the repository, then this will provide a level of quality control.

\section{CONCLUSION}

We believe that our authorship program proposal advances two institutional goals. First, the authorship program represents a rethinking of the seminar-style advanced writing requirement in light of recent concerns about the utility of all elements of the required curriculum. Second, it improves student-faculty engagement and promotes what we hope will be influential intellectual exchanges. Although we value these potential institutional benefits highly, we want to conclude by emphasizing the pedagogical purpose behind an on-line student repository. We premise our student authorship proposal on the notion that student-run journals are meant to help students. While students do benefit in enormous ways from law review membership, an authorship program would focus on developing all students' writing, research and creative problemsolving skills in a systematic and uniform way.

Cornell Law School faculty, students, and visiting scholars." About the Repository, SCHOLARSHIP@CORNELL L., http://scholarship.law.cornell.edu/about.html (last visited Feb. 13, 2017). Some colleges and universities, including Harvard and the University of Florida, also have repositories for student works. See, e.g., DASH: Digital ACCESS TO SCHOlARShIP AT HARV., https://dash.harvard.edu/ (last visited Feb. 13, 2017); UnIV. OF FLA. J. OF UNDERGRADUATE RES., http://ufdc.ufl.edu/JUR (last visited Feb. 13, 2017). 